\title{
LRMSC Grade 4, Subcutaneous Tissue
}

National Cancer Institute

\section{Source}

National Cancer Institute. LRMSC Grade 4, Subcutaneous Tissue. NCI Thesaurus. Code C121179.

Necrosis. 